\title{
Regional Chief Election Democratic System in Perspective of The Unity Government of the Republic of Indonesia and Democracy Pancasila
}

\author{
Mugeni $^{1}$; Joseph H. Fauzie Hasibuan²; Atma Suganda ${ }^{3}$; Ismail ${ }^{4}$
}

\begin{abstract}
Research on local elections The Democratic Government System in the Perspective of the Unitary Republic of Indonesia and Pancasila Democracy is based on normative legal research methods. Based on indepth analysis and assessment, it was found that inperspectives system within Indonesia as a unitary state in which there is only one government that central government has the power as well as the highest authority in the field of state government and given that the regional administration is simply an extension of the central government, the Central Government in this regard the President has the power to determine the system the local elections with the electoral system either directly or by indirect elections. However, when associated with a presidential system of government adopted, then the appropriate electoral system is a direct election by the election system this rakyat.dalam Which is in accordance to the law of Sila All four Pancasila. Therefore, Election should be implemented in accordance with the law of the democratic ideals of Pancasila the election system should be implemented with the consensus system in the legislature. To avoid a debate that is ongoing is not finished-finished matter of choice electoral system directly or indirectly in the elections, needs to be done again amendment to the provisions of Article 18 Paragraph (4) Constitution NRI 1945, which immediately gives firmness electoral system used in accordance with the spirit the fourth principle of Pancasila listed in the preamble of the Constitution 1945. for that, it needs a comprehensive assessment of patterns of implementation of direct elections or through Parliament.
\end{abstract}

Keywords: local elections. Unitary Republic of Indonesia, Pancasila Democracy

DOI: $10.7176 / \mathrm{JLPG} / 90-14$

Publication date:October $31^{\text {st }} 2019$

\section{A. Background}

The reform era, ${ }^{5}$ that occurred in Indonesia since 1998 in the field of state administration has been marked by a series of amendments to the 1945 Constitution from 1999 until 2002. The four-time series of amendments to the 1945 Constitution has changed the constitutional system of the Republic of Indonesia with a very fundamental change. ${ }^{6}$ In fact, because so many and fundamental changes were made, according to Isnaeni Mochamad Ramdhan, ${ }^{7}$ which occurred not more amendments, but there has been a replacement of the Constitution 1945. Along with that, also collapsed is also the view that was constructed by President Soeharto's New Order era that the Act of 1945 is worth the "sacred", ${ }^{8}$ and made it difficult to do any changes.

Amendments to the 1945 Constitution itself has significance for the development of democracy in Indonesia for two things: First, a constitutional amendment is a matter that is not possible in Indonesia before the

${ }^{1}$ Doctoral students of the Post Graduate Program Jayabaya University.

${ }^{2}$ Professor, Promoter, University Lecturer Jayabaya

${ }^{3}$ Co Promoter I Jayabaya University Lecturer

${ }^{4}$ Co Promoter II University Lecturer Jayabaya

5 In Politics treasures Indonesia, the notion of the reform era refers to the period after the cessation of Gen. (ret.) Soeharto as President of the Republic of Indonesia on May 21, 1998. See the Satya Arinanto, Human Rights in the Political Transition in Indonesia, Center for the Study of State Constitutional Law Faculty of Law University of Indonesia, in 2015, p. 57.

${ }^{6}$ Asshiddiqie, Principles of Constitutional Law Indonesia, PT.Bhuana Popular Science, Jakarta, 2007, P.xv

${ }^{7}$ Mochamad Isnaeni ramdhan, Changes in the Technical Amendment 1945, Sinar Grafika, Jakarta, 2015, p. 10. To discreption the changes made by the Assembly from 1999 to 2003 carried out periodically to 1945 partially. That is, in the first period in 1999 to amend 15 dictum, then the second term in 2000 to amend 59 dictum, followed by a third period in 2001 to 68 dictum, as well as the fourth period in 2002 to amend 29 dictum. Thus the total that has been done is a change of one hundred and seventy-one dictum including three chapters in the Transitional Provisions and the two articles in the Additional Rules..

8 Yusril Ihza Mahendra, Indonesia Constitutional Dynamics, Gema Insani Press, Jakarta, 1996, p. 12-13.. 
reform era. Because one political stance during the New Order is to complicate the 1945 changes were considered a sacred document and should not be inviolable. To complicate revise the 1945 Constitution has been issued by the MPR Tap. No. IV / MPR / 1983 Referendum. Second, an amendment to the 1945 Constitution is one of the essential requirements for the implementation of better democratization in Indonesia. ${ }^{1}$

One of the most fundamental changes were made in the 1945 changes is about the power of the People's Consultative Assembly (MPR), which originally as the highest state institutions and holders of popular sovereignty fully into regular higher institutions. ${ }^{2}$ According to the original text of the 1945 Constitution Article 1 (2), "sovereignty is vested in the people and performed entirely by the Assembly. The formulation of this provision was later changed to "sovereignty belongs to the people and carried out in accordance with the Basic Law."

Indeed, many experts in constitutional law, the provisions of Article 1 (2) 1945 is seen as the source of the supremacy of the Assembly, which puts the Assembly as the sole executor of the sovereignty of the people, the MPR as the embodiment of the people, and the Assembly as the highest state institution. Such MPR suggests that as if sovereignty has shifted to the Assembly, but the Assembly is merely the executor of popular sovereignty. According to Philip M.Hadjon, the existence of such institutions in the system MPR RI state institutions is a unique state agency. Its uniqueness is that such institutions MPR is difficult to find unequaled in any country. ${ }^{3}$ Therefore, in addition to various other drawbacks contained in the 1945 Constitution, the provisions of Article 1 (2) This is the key formula that undermines the constitutional system of the Constitution 1945. That is why, when the Assembly to amend the 1945 Constitution as one of the reform agenda, formulation Article 1 (2) has become one of the articles that do change. ${ }^{4}$

Other fundamental change of the provisions of the 1945 Constitution include the exclusion explicitly about elections (hereinafter referred to as elections), whether the election to fill the membership DPR, DPD and DPRD. Conditions mengenaai general election in 1945, primarily set out in a separate chapter, a new thing. ${ }^{5}$

One of the spirit of the reform is to democratize the process and implementation of the elections in the past, elections were held in the New Order era (the elections of 1971, 1977, 1982, 1987, 1992, and the 1997 election), known generally just a political ritual full five-year authoritarian political engineering, which is reflected in the legislation governing elections (electoral laws) and in the process of elections (the electoral process). Thus the election was going on here is not in the true sense, but rather "as if the elections" the result was predictable, that is just to keep themselves in power. ${ }^{6}$

In a democratic state of law, the election is one of the real form of democracy, although democracy is not the same as the general election. The general election is one very important aspect of democracy which must also be held democratically. Therefore, it is common in countries that call themselves democracies mentradisikan election of public officials in the areas of both the legislative and executive mauapun center in the area. Democracy and democratic elections is an absolute requirement interrelated with one another. ${ }^{7}$

Seeing some of the provisions in the 1945 amendment to the Constitution NRI as stated above stated explicitly that the selection of members of the House of Representatives, Parliament, elected through general elections, as well as for the election of the President and Vice President also expressly stated selection must be made directly by the people. However, for the election of Governors, Regents and Mayors as the head of government of the provinces, counties, and cities are not explicitly mandated to be carried out directly by the people, but is called by another term that is elected democratically.

Understanding election conducted "democratically" as defined in Article 18 paragraph (4) of the 1945 Constitution NRI, of course, can be interpreted in various in its formulation at the time of manufacture of the organic law, the legislation made to implement CONDITIONS provisions of the constitution.

That Law Number 22 Year 2014 regarding the Election of Governors, Regents and Mayors that regulate the local elections indirectly through the House of Representatives has got rejection wide by the people and

${ }^{1}$ Valina Singka Subekti, Making the Transition Constitution: The struggle of Interest and Change Process Thought in 1945, Eagle Press, Jakarta, 2008, p. xiii.

${ }^{2}$ Taufiqurrohman Syahuri, Constitutional Law, Process and Procedure Amendment of Constitution in Indonesia 1945-2002, Ghalia Indonesia, Bogor, 2004, p.218

3 Philip M.Hadjon, Top Institute and State Agency, Development Studies, Surabaya, p. Ix.

4 Anwar, C., Theory and Constitutional Law, Equal Press, Malang, 2015, p. 168

5 Refly Harun, Disputed Election Law, Election Results Dispute Resolution Mechanism in the Constitutional Court, the Constitutional Press, Jakarta 2019, p. 1

1

${ }^{6}$ A.Mukthie Fajar, Elections, Election Result Dispute and Democracy, Equal Press, Malang, 2013, p.24.

${ }^{7}$ idem, p. 27. 
decision making process has caused problems and crunch that forced the appropriate verdict The Constitutional Court Number 138 / PUU-VII / 2009.

Departing from the description of the background issues raised briefly above, in this dissertation research, the authors raised the title as follows "The local elections in the Perspective of Democratic System of Government of the Republic of Indonesia and Pancasila Democracy."

\section{B. Formulation of the problem}

There are two (2) fundamental issues to do research in this study. Two formulation of the problem is:

1. How do the local election system in accordance with the system of government of unity and in the context of regional autonomy?

2. How the local election system that is in accordance to the legal precepts of the four Pancasila?

\section{C. local elections in the Perspective of Democracy and Governance System of the Republic of Indonesi 1. Historical Development and Democracy in Indonesia.}

From the history and development, terecatat before foreign nations invaded the nation of Indonesia, the Indonesian life is already known the principles of democracy even in simple forms. According to $\mathrm{S}$. Toto Pandoyo, this is evidenced by the assortment of both state institutions and the nature of society, for example in the life of the state, namely

presence pepe rights (Sun) at the royal subjects in the political system of government in the first kings of Java. If there is a temporary or a lot of subjects empire intends to convey the aspirations of the king or queen, then they can do so by means of drying themselves (pepe) in the field advance performances (pendapa kingdom) so that the king or queen pleasing ask teentang reason why they do it, and whether No that would be submitted. The king or queen messages conveyed through royal servant. State's aspiration subjects (people) like it is in the political system of royal government, although in this way, but contains elements of democratic, though still in a simple form and temporal, but institutionalized.

One of the main objectives to amend the 1945 Constitution is the structuring of all state institutions in order to create mutual monitoring mechanism or the so-called system of checks and balances between state institutions. But what happened later during the four times the 1945 changes in the 1999-2002 period is not just addition and subtraction between the authority of the state institutions that already exist. There will be significant changes since then led to a state institution totally new and some state institutions were wiped from existence in the Indonesian constitutional structure. ${ }^{1}$ Hence the process of change that took place from 1999 to 2002 was qualitatively and quantitatively really has given birth to a new constitution. ${ }^{2}$

Prevent the accumulation of power to create a better democratic life is one purpose of the constitution. Therefore when all the factions in the MPR carries the proposed amendments to the 1945 Constitution for the first time in 1999, the key issues being discussed factions in the MPR is a matter of domination by the executive (the president) and the weakness of the legislature so peru ahan first focused on two issues the main, which limits the authority of the president and strengthen the role of Parliament. ${ }^{3}$ Because after all, if too dominant executive while the legislative power is weak, what happens is that excessive executive power (beyond habit or condition) that works without control, ${ }^{4}$ and that's what happened in the New Order.

In order to strengthen the authority of the House of Representatives, then one step MPR is melakukukan amendment to Article 5 (1) and Article 20 of the 1945 Constitution With the amendment of Article 5, paragraph (1) it reads: "The President is entitled megajukan draft to the Parliament", and followed amendment of Article 20 paragraph (1) it reads: "Parliament holds the power to make laws", then there has been a substantive shift of power in the legislative power or the power of the establishment of the laws of the hands of the president to the

1 As an example of the diminished authority of state institutions is the People's Consultative Assembly, while the agency increased authority is the Board of Representatives. Regional Representative Council and the Constitutional Court is a newly formed state agency. Sedangka erased state institution is the Supreme Advisory Council..

${ }^{2}$ Anton Djawamaku and M. Sudibjo, "Change 1945: Problem Solution and the Constitution?" Journal of CSIS Analysis, Year XXXI No.3., P. 291 Center for Strategic and International Studies, Jakarta, in 2002.

${ }^{3}$ Saldi Isra, op.cit. p.179

${ }^{4}$ Valina Singka Subekti, Loc. Cit. 
House hand. Thus the President is no longer in power formation of legislation, ${ }^{1}$ and that means is a significan reduction in presidential powers because it is so strategic power of the establishment of this law in the administration of state government.

Other significant changes to the 1945 Constitution is a model change election of the president and vice president election by representative institutions, namely by the Assembly be elected directly by the people as provided for in Article 6A paragraph (1) NRI Constitution of 1945. This provision was consistent with the theory in presidential system of government in which the president is not elected by the legislature. NRI Constitution of 1945 as defined in Section 7A also removed the accountability system president and / or vice president to be dismissed in tenure. In the new provisions, the president and / or vice president shall only be removed through impeachment mechanism (impeachment) when it has proven wrongdoing.

Then the 1945 changes also expanded the assertion system local elections or elections of governors, regents, mayors should be done democratically as specified in Article 18 paragraph (4) Constitution NRI 1945, that: "Governors, Regents, Mayors, respectively as head of the provincial government, District and Municipal elected democratically. "Although the phrase" elected democratically "not assert directly to the system of direct election by the people, but some of the law on local elections that were born then, most recently with UU.No.10 2016, has insisted the elections with a system of direct election by the people.

In conjunction with the provisions of the 1945 changes relating to democracy, and with regard to the presidential election as head of government and the election of governors, regents and mayors as head of government in the area (elections), seems not indicate a coherent relationship with the value of ideals of law contained in essence staatsfundamentalnorm, namely the values of Pancasila.

\section{The position of Pancasila in Indonesian Democracy}

In the previous chapter has dikemukkan, that the development of democracy in various countries, seen the influence of ideology on the lives of democracy in the political system, giving rise to various types of democratic governance in the country. When an ideology has been used as the basis of state, or have an ideology of state which is dominant in the political system, then at least the ideology of a state that may affect the democratic life of the country concerned, or to the maximum can form this type (pattern) of democracy itself, or minimally provides the properties or special characteristics to a type of democracy.

Indeed, in practice, there is a type of democracy which is basically derived from the influence of a particular state ideology, but there is also a combination or a gain influence between ideology to one another. ${ }^{2}$ In connection with that, a step that needs to be done also to discover more about the position and influence of Pancasila as an ideology and country basis as well as in functions other against a pattern or type of democracy practiced in Indonesia, and then to do that important anyway after that with the implementation of election of regional leaders or election.

Indonesian nation as a sovereign state formally to exist and exist just after the proclamation of independence on 17 August 1945. However, the proclamation should be argued in such a way as peak very long struggle which is based on the ideology of the people who dug up, grow and develop in the lives of the people of Indonesia ${ }^{3}$

In a later development in the political and constitutional history of Indonesia, Pancasila is not the basis that only static state. From the history of excavations up to the inauguration as the state Pancasila it is dynamic. Dynamism is confirming Pancasila without anyone menyangsikanya become a way of life, the philosophy of the nation, national ideology, national identity, the source of all sources of law and order, the destination country, the agreement of the noble nation of Indonesia, which require performance and its safety in the community, the nation and the state in question ${ }^{4}$,

${ }^{1}$ Wicipto Setiadi, "The Meaning of the Joint Agreement on the Establishment Act and the signing by the President on the draft legislation has been Approved Together", Journal of Legislation Indonesia, Vol.1, No.2., September, p. 21 The Directorate General of Legislation Ministry of Justice and Human Rights, Jakarta, in 2004.

${ }^{2}$ S. Toto Pandoyo, op.cit. P.45

${ }^{3}$ See: Drafting Team. Encyclopedia of Political Development Foundation Tjiptaloka Pancasila vol 3. Caraka, Jakarta, 2003, p. 277. This understanding is based on the long journey of the history and journey of Indonesia which was crystallized sociocultural aspects of the Indonesian nation.

${ }^{4}$ Soehino. Glance About Resources Law of the State of Indonesia.LibertyYogyakarta, 1981, p. 16. An understanding of the various concepts and reflections Pancasila as the basis, essentially juridical meaningful. Pancasila as the source of all sources of law in the Republic of Indonesia. More fundamentally, is how the Pancasila was implemented in everyday life. 
In practical terms, the life of the community, nation and state of Indonesia, Pancasila role or implementation of multi-dimensionally can be described as follows:

4. As the foundation of the country, Pancasila the basis / foundation of and procedures for the implementation of state in order to achieve the ideals of the independence of Indonesia.

5. As the outlook of the nation, Pancasila support and sustained by the Indonesian people in the whole series of round and intact on all mindset, initiative and work towards existing and human existence as Indonesia, both individually and socially. Pancasila is a lifeline that gives directions at once content and a solid foundation to achieve the ideals of the Indonesian nation.

6. As the nation's philosophy, Pancasila is the result of a thorough process and in-depth thinking about the nature of the Indonesian nation, so it is the right choice and the only one to act as the Indonesian people in the life of society, nation and state. The nation's cultural values of Pancasila has become normative ethics, generally accepted, human and fundamental, which is constantly nourished in the process of being and becoming fully human Indonesia.

7. As a national ideology, Pancasila does not only regulate relations between Indonesia, but has become political ideals at home and abroad as well as guidelines for national achievement which is believed by the people of Indonesia.

8. As the personality of the nation, Pancasila is a unique selection of the most appropriate for Indonesia, because it is a socio-cultural mirror of the Indonesian nation since the existence in the archipelago.

9. As the source of all sources of law and order, Pancasila occupy the highest position in the sort order of the state legislation of the Republic of Indonesia. That is, all regulations, laws, positive law must be sourced and are intended for the implementation of the values of Pancasila.

10. As the purpose of the state, real Pancasila role, because the fulfillment of the values of Pancasila was tightly attached to the struggle of Indonesian nation since the Declaration of Independence August 17th, 1945 until now and in the future. National development pattern should show determination Indonesian nation to achieve a just and prosperous society based on Pancasila.

11. As the agreement is sublime, because Pancasila excavated from the socio-cultural Indonesian people themselves, agreed by all the people of Indonesia as something to be secured and preserved. Inheritance Pancasila values to future generations is a moral obligation of the entire Indonesian nation. Melalaikannya deny the sublime agreement and thus deny the nature and dignity of ourselves as human beings.

12. For more technical applications, in a sense as a translation of Pancasila for the communal life of the nation should be understood how the position of Pancasila as noted above. It memeprkokoh position of Pancasila as the basis for the entire life of the community of Indonesia. ${ }^{1}$

\section{Election Law in Perspective Countries Indonesia}

In the perspective of a democratic constitutional state, which became the core of the people's sovereignty is basically reflected in the form or system of government that all citizens participate ruled through wakilnyanya representatives in the legislature. Or also known as the people's government entirely based on legal provisions which have been made by the legislature as an institution of the legislators who are landasar normative requirements of state law ${ }^{2}$

1 ibid,

${ }^{2}$ See inside Big Indonesian Dictionary (Jakarta: Balai Pustaka, 2008, Ed. Third, Fifth Matter), p. 249. An understanding of the rule of law reflects the consistency of the implementation of the government machinery is fully based on the law. 
In the history of the emergence of the law states that the root of its existence is of democracy itself. Democracy for the first time is known is that direct democracy, where all citizens to participate in the deliberations real to determine the general policy or legislation. Of provisions of the law is then flowing various provisions which reflect the consistency of the basis of state law. ${ }^{1}$

State law based on the principles of democracy is a concept which means government by the people. Or often stated that democracy is government of the people, by the people, and for the sake of the people. It is the people who berdulat in the administration of state government, and create and define and then implement the law. Even the court were to take legal action against the infringer also selected based on the mechanism prescribed by law. Those who sit in this institution was performing on the basis of law.

The above is an element which is like object with two sides. The first side is democracy and the reverse side is a constitutional state. From this conception, it turns out that in addition to the principles that exist in a state of law, and democracy is also an element of a set of practices and procedures of a process of institutionalization of freedom that is long and winding. This is the need for regulation and the essence of the state of law.

State law with the rule of law will not be separated from the basic conception that is used as the foundation for creating a national state at the level of state and supreme law called the constitution. This is the basis of a universal applicable in each country.

At the level of the corridor constitutional, then the question of the rule of law is embodied in a national community called state constitutional law, which is a country where every action of the state officials, the government and all equipment in the country at the center and in the regions to the people must be based on law term specified by the folk / her representative in the representative body of the people. ${ }^{2}$

According to the principles of popular sovereignty that is, in the democratic state of law is made to protect the rights of human rights of citizens, protect them from the action beyond the legal provisions and to realize the social order and the rule of law and justice so that the political process goes peacefully in accordance corridor constitutional law.

In conjunction with the foregoing, the constitution of 1945 NRI fact have the basic measures that can be used to realize the law of the country where the rule of law will be realized. Constitutionally Constitution NRI 1945 explained that Indonesia is a country based on law, not based on power. This is a Grundnorm that has been dug up and agreed by the founding fathers who built at the beginning of this country stands. They are the founders of this nation has provided guidance, how to construct a state of law, how the state law will be directed, in the sense of what we realize the state these laws, once required to enforce the law as one of the instruments that can be used appropriately in realizing the desire or ideals of the nation. ${ }^{3}$

In order to better actualize the ideals konstitutusioalisme actually based commitment to democratic values and the protection of the rights of human constitution, the most important thing to do now is how the Indonesian nation is able to continue to improve, especially with regard to the development of national laws to be able to be the ideal of national law. If the development of national law has been directed to the development of an ideal law then the law can be an instrument in order to achieve national objectives of Indonesia as stated in the fourth paragraph of the Preamble of the Constitution of 1945. However, the political will of the government is the main capital for the realization of development national law and the obligation of governments to realize the objectives of the country,

These objectives are pursued its realization through development undertaken gradually and continuously in the program short, medium, and long term.

Based on this it should fit with the view of Satjipto Raharjo, that keresahannya against Indonesian law states accompanied by an expectation that the law should make people happy, it is not difficult and is not painful. Above all the debate about the state of law in view Satjipto Rahardjo, may need a confirmation of the perspective that the state of the law is for the welfare and happiness of the Indonesian people, not vice versa. Law should not make life more difficult. This is what should be the size of appearance and success (standard of performance and result) Indonesian law states. ${ }^{4}$

${ }^{1}$ Conceptualization and development of the House of Representatives of Indonesia, Student Library. Yogyakarta, $2014 \quad$ Kusnardi and Bintan R. Saragih, State Science, Revised Edition, Style Media Pratama, Jakarta, 1988. p. 165.

${ }^{2}$.. Regarding the principle of representation, see for example in the book Samsul Wahidin.

${ }^{3}$ Padmo Wahjono. op.cit, p. 202

${ }^{4}$ Ibid.p. 79 


\section{Perspective of the elections in the Republic of Indonesia}

In discussing the elections in the perspective of the Republic of Indonesia as well and should begin on a comprehensive understanding of the definition of the state, the form of state and government system in general. Because after the elections that will produce executive leadership in that area, in turn, are closely linked to systems of governance in the country, both in the provinces and districts / cities.

According to modern theories presented by Kranenberg stated, that the state is an organization of power created by a group of people called the nation. While Logeman said that the state is essentially an organization of power that includes or unite groups of people called the nation.

The idea of two states is essentially an organization of power to achieve a certain goal as agreed and determined. Or it can be said that establishing a state is essentially founded and formed the organization of power. ${ }^{1}$ The visual power can be divided in two ways:

1. Vertically; namely the division of power according to its level and in this case the government level. Carl J. Frederich used the term territorial division of power (territorial devision of power). This power-sharing can clearly be seen if we compare the unitary, federal states and confederations.

2. Horizontally; namely the division of power according to the function. And this division shows the distinction between the functions of government are legislative, executive and judicial, better known as the theory of separation of powers in the Trias Politica and the division of powers, as the theory of division of power. $^{2}$

State may be called unitary state if the central government and local governments are not equal and not equal. The central government is the highest authority in the country, as well as a central legislative body in shaping legislation. Local government authority is derivative (indirect) and often in the form of broad autonomy, so it does not recognize the division of national and local legislative bodies are equal.

Explore the concept of a unitary state to be important in terms of scientific research as a theoretical foundation in order to issue the electoral system and the organization is not out of the level of the concept of the Unitary Republic of Indonesia where local autonomy is not interpreted as 'sovereignty' area but must remain within the framework of the Unitary State of the Republic of Indonesia, In such a perspective should be understood as a philosophical and juridical, that there is no such thing as local independence really independent in the true sense. The region's autonomy in this context remains in a limited sense, and is controlled by the interests of the central government.

\section{Structural and Cultural Dimensions of Direct Election}

Before discussing further about structural and cultural forerunner direct election, first need to be done prior to the terminological clarification between the Regional Head Election (Election) or Regional Head Election (Election). The conceptual clarification is needed as a basis for the elaboration of further problems.

Based on an inventory-related legislation, as set forth in some of the legislation, that this clarification can be traced from Chapter VI Regional Government in Article 18 of the Constitution NRI 1945, Law No. 15 Year 2011 on the Implementation of Elections, Law No. 12 of 2008 on changes to Law No. 32 Year 2004 on Regional Government, to Law No. 102016 (the last change of the Electoral Act Governors, Regents, Mayors) which now serve as the basis for implementing the election.

By the time the election was initially not classified as election with reasons not mentioned in the article that regulates elections set forth in Article 22E of the 1945 Constitution NRI is precisely a matter of election governed by Chapter concerning regional government, which in Article 18 Paragraph (4) Constitution NRI 1945. hence the term "electoral regime" and "regime" completely previously unknown treasures of political science as well as in the science of government. The elections are not categorized as elections for not mentioned in Section $22 \mathrm{E}$ of the governing elections, and categorized entered as the regime as set out in Chapter IV of the Constitution NRI 1945, namely in Article 18 Paragraph (4). Then pengkatogorian election is not an election followed the lawmakers who gave birth to UU.No.32 2004 on Regional Government.

In the UU.No. 32 of 2004 on Regional Government did not confirm the elections as elections. In any of its provisions are not there or do not find the term or phrase "Election" Governors, Regents, Mayors. Provisions that directly defined as "Election of governors, regents, and the Mayor."

1 Sri Sumantri and R Bintan Saragih, Indonesian constitutional in Indonesian political life (30 Years Back To Act of 1945), Pustaka Sinar Harapan. Jakarta, 1993. Pg. 4.

${ }^{2}$ Miriam Budiardjo. PolitiC PT Basic Sciences. Gramedia Jakarta, 2001, p 138. 
Now the direct election which in the past carried out in particular to choose the lower-level leaders (such as village heads in Java) is no longer simply a discourse. Elections, both at the level of the governor or regent / mayor has become a reality and be realized through legal statute. The Election Day was realized in mid2005, as a follow up of direct presidential elections that have been successfully implemented by the Indonesian people without obstacles.

Direct local elections brought a fundamental change in the aspect of public administration and further also on aspects of state administration as a consequence of the change in the system of peaceful transition of power at the national level that is chosen directly by the people's president. Substance direct election also brought a change in the administration as well as the cultural patterns of the community in the area. This is due to its strategic position in the region head institutions of local governance system should indeed require close emotional relationships with people. ${ }^{1}$

Local elections are held directly by the people, is a manifestation of the people's democratic demands voiced strong on after the end of the New Order government, which is actually rated by many as the culture of Indonesian society. Democracy in this regard is not interpreted as substantive as coming from the Western world, but rather is a manifestation of people's political rights are fundamental in choosing a leader, in this case the head of the region, particularly in the context of the implementation of regional autonomy.

In connection with the culture of local elections give the public democratic space in order to carry out their political rights. This is the antithesis of the elected seats previously held, where people just used as jargon democracy to be legitimized by the people's representatives. Whatever the decision is a decision of the people's representatives themselves. The assumption was born that the rights of the people have been represented by representatives entrusted to sit in parliament and obtained as a result of democratic elections. So far, this interpretation is acceptable because it is born of the concept of sovereignty as stipulated in the 1945 Constitution before the amendment that outlined, that sovereignty is in the hands of the people and carried out entirely by the people's Consultative Assembly as the highest institution.

In the cultural perpsektif, in particular linked to the history and development of local government in Indonesia, various groups considered that it was time held direct elections. This is indicated by the increasing openness of the community, the community and the more advanced smart mindset, which means increasing complex needs that have implications for the increasing and diverse demands that must be accommodated by a leader.

With this structure will change in the future will be cemented the position of a person in a formal leadership arena. Conceptually, the idea was the basis of the principle of legality konstitusioanlisme which requires every basic policy should be based on a constitution that is rooted in the culture of society. Thus the policy that will be taken involving the public directly as part of public participation, also in the mechanisms of governance. This means that in formulating the policy, people do not simply rely on their elected representatives have been chosen in the legislature. But the people also appoint the leadership at the executive level to then together with legislators make policies in order to realize the welfare of society itself.

Along with the true culture shift people realize it or not, the pattern of culture of Indonesian society further and further towards the individualistic culture. Thus the pattern seen with the increasingly waning niolai community values and replaced with individual cultures. The tendency, which is directed at a materialistic lifestyle became the main feature of the individualistic culture that has implications for the increasingly diverse demands that must be met by a leader.

\section{Analysis System The democratic local elections in the Perspective of Governance System Unitary And Pancasila Democracy}

\section{Dynamics of Electoral Implementation At the beginning of the Reform Era}

The organization of local elections is related to governance in the region, and therefore it is of course closely related to the implementation of regional autonomy. In this regard, the debate on autonomy from time to time continue endlessly. Moreover, after the Law No. 22 Year 1999 on Regional Government and Law No. 25 of 1999 on Financial Balance between central and local governments came into effect. Enforcement of the laws is indeed a new era in government in Indonesia, where the areas being given autonomy in running the government. ${ }^{2}$ Some even say that the spirit within UU.No.22 1999 it was smelling federative spirit and terms of

${ }^{1}$ Society.Panepen Mukti. Surakarta. 1983. The book is now peeling leadership that was located at the cultural society, especially Indonesia.

2 UU no. 25 of 1999On Financial Balance between central and local government is seen as a sort of diversification or expansion of the substance of the regional administration, which previously always set in the Act. Issues relating to the 
the way the local elections and heads to the area in which the position of Parliament is too strong, there has been a kind of parliamentary government at the local level. Whereas in the unitary state with the presidential system of government, never met the executive accountable to the legislature despite the dominant principle of decentralization implemented.

As a result there was a power struggle never imagined in the past. Friction occurs in particular not only between districts / cities in the province, but also among government administrator in the area, which is between the governor with the regent / mayor of the district administrator with the vice regent, or the regent / mayor with Parliament. Even with the law in local politics a kind of a victory party parliament with their parent political parties to exert pressure on the governor or regent / mayor. Although significantly it as just a stage, because it boils down to is a kind of division or distribution assets to two power areas in question, so that the implementation of ineffective governance in the region. ${ }^{1}$ Even bear the political costs are expensive.

In terms of implementation, the management authority often led to friction between the governmental levels that tend to disrupt public services. The establishment of local devices is often less oriented towards improving services, and only oriented to meet the formal administrative. This resulted in the emergence of inefficient organizational structure (structure rich, poor function). Personnel management based on separated system, creating patterns that tend ethnocentrism ${ }^{2}$ and the limited mobility of employees in career development. Meanwhile, on the utilization of the budget more for shopping menuntup device apparatus and the DPRD, so the opportunity to improve public services and quality excellence becomes smaller.

In a political perspective, that during the passing of regional autonomy in accordance with Act No. 22 of 1999, has formed a public opinion that there has been excessive autonomy. Which focuses on legislative powers (legeslatif heavy) merejalela in the district / city. There is an opinion that there is some sort of imaginative or untruth irregularities in the implementation of regional autonomy district / city.

The regents / mayors as already being away from the substance of the ideal of autonomy itself: there euforea authority at the district / city, which in turn give rise to the impression of the tendency of indifference or non-compliance on the part of the district / city to the provincial government, so that for this there are many stories politics of the characters rather than the actual substance of regional autonomy.

In another perspective, there has been a change in national government systems, including semiparliamentary system to a presidential system, and of the indirect presidential election to the presidency langsug. It is then supposed to be followed up to the local level. Strictly speaking the occurrence of a fundamental change at the central level or changes in national government systems involved have a big hand in the changes that occur at the time of the enactment of Law No. 22 of 1999.

On judicial perspectives, that there are some laws which published alongside whom the law on the composition and the position of Parliament in 2004 which no longer includes the authority of Parliament to elect regional heads. Therefore urgently needed a mechanism to elect the head area, so as to ensure their consistency with what happens level of national government (eg direct presidential election), the head of the region need to be elected directly by the people and automatically there should be laws regulating elections direct regional head (elections).

Specially with regard to piilkada peyelenggaraan system should also be elaborated in such a way because it is one of the important things in the implementation of regional autonomy in the reform era. As already noted in the Introduction, that one of the demands of the reform is to create a democratic system of government, both at the center (the President) to the region (Regional Head). Embodiment of the spirit of democratization of leadership at the local level mandated in the 1945 Constitution (Amendment IV) is the local elections to be held democratically according to demand political reform. Therefore the demands perfection of UU.No.22 1999 coming from various parties, not only concerning the administration of government, including the supervision of both vertical and horizontal, but it includes also involves a system or mechanism of local elections. It is also more legitimacy after the occurrence of a fundamental change the mechanism of election of

implementation of the set in the implementing rules under the Act. With this Act in respect of the financial issues are regulated separately, regardless of the parent Act is law 22, 1999..

${ }^{1}$ A formal consideration UU.No.22 surrogate birth of Act of 1999, namely Law No. 32 Year 20-04 On Local Government is:that the efficiency and effectiveness of local governance needs to be improved with more attention to the aspects of the relationship between levels of government and inter-government regions, the potential and diversity of the regions, the opportunities and challenges of global competition by giving authority as possible to the area accompanied by the granting of rights and obligations held regional autonomy in the unity of the state governance system;

2 by ethnocentrism is attitude or outlook that stems from the society and culture of their own, usually accompanied by a dismissive attitude and outlook that society and other cultures. In Administrative Law called sa sectoral ego, and this is a challenge that must be removed. 
President and Vice President directly by the people as set in Article 6A Paragraph (1) Constitution NRI 1945 (Amendment 1945 third stage).

One direction of change that ensues involving the substance is within the framework of the democratization agenda against the will of the people in the region in terms of the appointment of a leader. At the time of the discussion of Article 18 in particular paragraph (4) of the 1945 Constitution, the Assembly has been basically agreed to open a wide space for the freedom of the area in the electoral process Kapala area. Meaning the area of freedom in determining the formal leaders, among others interpreted by implementing direct election to the region. Construction formulation of Article 18 paragraph (4) NRI Constitution of 1945 can be regarded as the forerunner to the implementation of direct elections are held in the area.

In essence, that concretely format shift has taken place in the determination of public offices, from the regime of election of representative bodies in the direction of the election or electoral regime. That means a variety of instruments that became the basis of the administration of elections shall be the basis for the election of the leader of the people. In simple terms this format requires all the organization, ranging from the preparation, implementation until the evaluation is really involved and exercised directly by them. Therefore, direct election by the people it was then echoed and packaged in the language of the people as well, namely the democratic party of the people.

\section{The existence of direct elections in the Perspective of Politics, Law}

In political perspective in Indonesian electoral law, election law in Indonesia - and of course including the law on the election - will never be separated from previous experiences that tend to be semcam instrumental or trial process that is not finished-finished. It happened as stated by Mahfud MD., Who has been mentioned in the introduction is due to three things. First, because of the electoral operations have been carried out always contains a weakness that later became an argument as to improvement. Secondly, due to changes in the political configuration that requires changes in the system and mechanism election motives of course motivated by certain political interests by political parties that exist. Third,

The arguments mentioned above are certainly no exception will continue to apply to political current election law, especially against direct election system hitherto applicable. Moreover, the argument is strengthened by the philosophical foundation and a strong constitutional. For example, as noted earlier, under the provisions of Article 18 of the Constitution Subsection (4) NRI In 1945, the phrase "elected democratically" can be interpreted in the election system of direct elections by the people or can be by means of the electoral system through a parliament or elections to the representative system. Throughout the construction of constitutional law pursuant to Article 18 Paragraph (1) of the 1945 it was so or not changed, so long as it is also the electoral system used may change over is preferred by most of the political parties in parliament. It is thus clear that the legislation to accommodate the direct election today, in the future there is a possibility to do a change to the system of indirect elections.

Various studies about the relationship between state and society there is a typology based on two criteria, namely: "whether the country is independent and whether it guarantees the public interest". ${ }^{1}$ The main consequence of the strengthening of the state is crippling the dynamics and the creative power of civil sociiety, which at a later stage will hinder the country's development process in the fields of politics, economy and culture extensively. Conversely, when the state is too weak, it will lead to anarchy. The balance between the state and civil society is a normative model that is constantly sought by the thinkers of the third world, because it is a prerequisite for the gesture and the desired transition towards democratization.

That direct elections or indirect election is two systems are equally gaining recognition constitution as stated in Article 18 Paragraph (4) NRI Constitution of 1945. That is in fact available options in the constitution. Which one is used, surely must be considered as well as possible through democratic channels anyway. Voice of the people in both structure and political infrastructure that exist within the political super-structure must both be accommodated within the framework of building a nation's strength.

The existence of direct elections in the political perspective of the laws of Indonesia as stated above imply the absence of a consistent choice. In addition to the constitutional under Article 18 Paragraph (4) 1945 which shows the phrase "elected democratically" does not mean only be interpreted as a direct election but can also diinterpresikan can be selected through a system of representation, as well as a choice of systems depends also on the attitude of the political elite in parliament, Even in the history of democracy in Indonesia also shows, a democratic system can change at any time in accordance with the wishes of the regime.

${ }^{1}$ Miriam Budiardjo. Loc. Cit. 


\section{Direct local elections in the framework of the Unitary State System}

Has dikemuakan above, the constitutional system of direct election and indirect alike have actually legitimized in the Constitution NRI of 1945. Under the provisions of Article 18 paragraph (4) Body of NRI Constitution of 1945, the election system can be done either by direct election system or by indirect election by the people's representatives in the legislature or by the parliament area.

Departing from the general definition of the state of unity as a country which is not composed of several countries (read: state), but only made up of the top of the country so that no state within a state, it is thus within the unitary state there is only one rule that government center that has the highest authority in the administration of state government. However, as already noted, in governance within the unitary state known two forms of system used, namely:

First, a unitary state with a centralized system, which everything was arranged immediately and administered by the central government, the regions only stay implement. In that regard, it is not just all the organs in the area, but includes all personnel who administer local government is central apparatus. Including in this case the regional head who is responsible in leading governance in the area is representative of the central government in the region and is responsible to the central government, in this case the president as the head of the supreme government.

Second, a unitary state with a decentralized system, ie to the region given the opportunity and the power to regulate and manage their own household (autonomous regions) called by the autonomous regions. In the implementation of the principle of decentralization must still be interpreted that all governmental responsibilities remains the responsibility of the central government. If one's own autonomy implies the right, authority, and responsibility for managing the household own country, but everything is just on matters dilipahkan to the region. So independence or freedom gained independence and freedom is not absolute, but is independence and freedom is granted or delegated to the regions, which must be withdrawn by the government.

\section{Direct local elections in the Framework of Regional Autonomy}

As described in the previous chapter, in a unitary state, there is also a system of governance with decentralization, ie the area given the opportunity and authority to organize and manage their own household called autonomous region. 1945 Constitution of Indonesia since the beginning has been affirmed espoused the principle of regional autonomy in penyelenggaan government. This was reflected in the mandate of Article 18 UUD 1945 before changes in Indonesia over the area of the division of large and small areas with the shape and structure of government is established by law.

In the perspective of Local Government administration, local autonomy was interpreted as the authority to regulate and manage the household area. There is also interpreted as the freedom or independence, though not in the sense of freedom in the sense regardless of the frame of the as its parent. In this sense it is a freedom in a limited sense, or independence was realized giving an opportunity that must be accounted for, both internally and externally. Accountability is in the frame as a unitary nation state final form. ${ }^{1}$

In another perspective, regional autonomy is also seen as a right ${ }^{2}$ to regulate and govern their own areas. That right source is the delegation of authority delegated by the central government as a reflection of a shared commitment that should always be used as the primary basis of government implementation. The Central Government is a representation of a unitary state which has the sole authority, in the sense that is structurally on Local Government. Run government administration should always be oriented to the unitary state as essentially meaning as in section above has been described in such a way.

In the perspective of the division of government in the context of a unitary state, regional autonomy is a government by and for the people on the territory or in areas of Unity State authorities. Is a reflection of government (central government to be exact), which then lays out the will of the state over the management of that area is a range of policies are made and implemented. In this regard, the regional government as structurally under the Central Government. Despite the application does not always refer to this condition. The phrase that "The Center is the headquarters of Regional and Local Government Area of center is' a logical consequence of it.

${ }^{1}$ WJS Poerwadarminta. Indonesian General Dictionary.PN. Pusataka hall. Jakarta, 1976. hlm..103, vocabulary-free, meaning is separated completely, undisturbed and not blocked by anything ..

2 Idem, p. 339. The lexical meaning of the relevant rights to this true adaklah power over something or to demand something .. so the dimensions that must be met, as a reflection of the institution. In this case, the institution in question is Regional. 


\section{Based on Pancasila Democracy in Indonesia}

Especially with regard to the democratic model adopted by Indonesia is known as Pancasila democracy, a democratic model inspired by the values contained in the five principles of Pancasila. In the development and practice of constitutional politics in Indonesia, Pancasila democratic model there are different interpretations and views. But in view of the system of state governance highlighted in the Preamble, the Body and Company 1945, Indonesian democracy menganutaliran constitutional democracy.

The purpose of the establishment of the people's representative body or agency itself, is to be transferred (delegated) powers to implement the sovereignty of the people, of all the people as the owner, to the proficiency level of representative institutions, as holder of power (mandatorily) ${ }^{1}$ which has been given by the people.

In its history, democracy has never been a topic that is so warm as it is now. In a democratic system that is old and well established in Europe and America, some citizens of middle demanding greater democracy implementation; while others demanded the gaps in democracy abolished.

Seen in general, the democratic system, either directly (direct) or indirectly (indirect) or representative, in its implementation need to use an organization that is a multiple, which means that no berseorang, but that berbanyak people, arranged in a variety of furnishings state. However the good of democracy as a state goal, but in the implementation of that vision will arise many difficulties and always requires the consciousness of the people, by considering the proficiency requirements (in terms of education and progress) and materill (perongkosan and so on) are not small. ${ }^{2}$

\section{Election Systems in Historical Dimension Sila All four Pancasila}

In the historical dimension, the philosophy of mutual cooperation and consensus in a democracy in Indonesia can be extracted from the process of the birth of Pancasila as the state. In the fourth principle of Pancasila is a sentence that reflects the consensus in question. In this perspective based on interpretation of the law can be used as a historical interpretation. ${ }^{3}$

Observing the birth of Pancasila, there are three speeches expressed in Independence Business forum Investigation Agency (BPUPK) is a speech delivered by Muhammad Yamin, Supomo and Ir. Sukarno. Third conveys independence figures, that the constitutional structures and mechanisms should everything be resolved in the legislature by consensus. ${ }^{4}$

In the development because of the influence of Western culture, then enter liberalism. Making of democracy elected directly by the people, by taking lessons from the Ancient Greek. A time when the number of people still few and territory that is not too broad. Thus every member of the community or the people can participate directly in deciding the issues together, particularly in the selection of leaders. ${ }^{5}$

Liberalism was later adopted by the West with the US-led hegemony, especially in the case of the presidential election. ${ }^{6}$ But in the end the United States also did not apply the direct presidential election system is pure, because they use a district system where senators as representatives of the people who decide who the next

${ }^{1}$ Harmaily Ibrahim, People's Consultative AssemblySinar Bakti, Jakarta, 1979, p. 15

${ }^{2}$ Emery Reves, A Democratic Manifesto, (Translated by AZAbidin) Promulgation of Democracy School, Jakarta Development Foundation, 1951), p .. 30

${ }^{3}$ One of the critical commentary in understanding hukum is a historical interpretation. This interpretation method of historical word or history, which includes the drafting history, but further back to also pay attention to the opinion of experts from the past that have become comminis oppiniodoctorum. Historical interpretation is done by investigating the origin of the text of a legal ystem that never applies. See: Sudikno Mertokusumo, Discovery Law, Liberty, Yogyakarta, 1998. This book covers the legal interpretation.

${ }^{4}$ Book review on this matter, which is a translation of the shorthand minutes of the meeting BPUPK written by Muhammad Yamin, Manuscript Preparation of Indonesian Independence, published Jajasan Prapantja Jakarta, in 1959 and then taken over by the State Secretariat, with the same content was first published in 1983, with the title: Minutes of the sessions of the Association BPUPK. RI State Secretariat. Jakarta.

${ }^{5}$ Miriam Budiardjo, Op. Cit.P. 73

6 Look Book: Outline of American History, published by the United States Information Agency (United States Information Agency), published 1949, p. $442 \mathrm{ff}$ dinyatakaan that Elections, broadly held every even-numbered year in the federal and most state and local governments for various positions in the US. Some state and local regions holding elections every odd year. Every four years, an American citizen choose to 435 members of the US House of Representatives and approximately one-third of the 100 members of the US Senate. Each senator's term of six years. There are two basic varieties US elections: Election primaries and the general election. Preselection done before the elections to nominate candidates of the party will advance to the general election.. 
President of the United States. ${ }^{1}$

In the argumentum a contrario interpretation ${ }^{2}$ clear that the local elections by the people contrary to the values of Pancasila, particularly the principle of all four. Whereas in the Pancasila more emphasis on the representation system through the principle of consensus, as a reflection of the nature of mutual cooperation of the Indonesian nation into cultural roots and basic troubleshooting.

In this connection there is a judgment that is the true essence of Pancasila democracy and the rights of people in various areas of life. In the elections the political perspective through DPRD is considered more likely as the ambitions of the political elite. Reflecting the pattern of political games who want to satisfy ambitious politicians gain power. However, such interpretations can be eliminated by the fact that the leader must meet the requirements that essentially are siding with the people on the basis of honesty.

\section{E. CONCLUSION}

\section{Conclusion}

From the description and analysis relating to the electoral system and the holding of democratic local elections in the perspective of Pancasila democracy as described in previous chapters can be concluded:

1. Which system to the local elections in accordance with the system of government in the perspective of the Republic of Indonesia and the principle of local autonomy can be summed up as follows:

a. In the perspective of system within Indonesia as a unitary state in which there is only one government that central government has the power as well as the highest authority in the field of state government and given that the regional administration is simply an extension of the central government, the Central Government in this regard the President has the power to determine system of local elections was good with the electoral system directly or by indirect elections. However, when associated with a presidential system of government adopted, then the appropriate electoral system is a direct election by the people.

b. In the perspective of the implementation of the principle of decentralization which gave birth to regional autonomy, meaning the area was given independence in relation to the manufacture and decision-making regarding the interests of its own country. If the already autonomous region, that area can be said to have been powerless to do anything independently under the control and supervision of the central government. If the self-reliance and empowerment is interpreted specifically in self-reliance and empowerment in the field of democracy and politics, in the implementation of regional autonomy it should provide ample scope to people in the area to choose the head of its own country democratically, in this context, is a system of direct election by people.

2. Which of the elections system in accordance with the law ideals of Pancasila Sila All four can be summarized as follows:

a. Based on legal ideals embodied in the fourth principle of Pancasila as, Indonesian democratic system requires no direct democratic system based on the principle of consensus in an institution representative of the philosophical and constitutional Preamble patented in 1945. Therefore the system direct local elections by people are not in the spirit of the four precepts of Pancasila.

b. Article 18 Paragraph (4) Constitution NRI 1945 provides the constitutional basis similar to the system of direct election by the people or indirect election by the legislature, but local elections are indirectly representative bodies higher degree of constitutional than the election held directly by the people. This argument is based ideal of representative democracy contained in the precepts of the four Pancasila as the state and the source of all sources of law contained in the 1945 Constitution that the position of

\section{${ }^{1}$ Ibid.}

${ }^{2}$ Interpretation contrario is an interpretation based on the resistance between the problems encountered with the subject matter of legislation, Sudigno, Op Cit. p. 89 
philosophical and hierarchical constitutional as staatsfundamentalnorm higher than the provisions contained in the body of the 1945 Constitution itself,

\section{Suggestion}

1. In order for the elections carried out in accordance with the ideals of Pancasila democracy law the election system should be implemented with the consensus system in the legislature.

2. To avoid a debate that is ongoing is not finished-finished matter of choice electoral system directly or indirectly in the elections, needs to be done again amendment to the provisions of Article 18 Paragraph (4) Constitution NRI 1945, which immediately gives firmness electoral system used in accordance with the spirit the fourth principle of Pancasila listed in the 1945 opening.

3. A comprehensive assessment needs to be done on the pattern of elections directly or through Parliament.

\section{A. BOOK}

\section{BIBLIOGRAPHY}

A.Mukthie Fadjar, Pemilu, Perselisihan Hasil Pemilu dan Demokrasi, Setara Press, Malang, 2013. Abdul Hakim Garuda Nusantara, Politik Hukum Indonesia, YLBHI, Jakarta, 1988

Abdoel Muin, Pola Kepemimpinan dalam Masyarakat Pluralis, Penepen Mukti, Surakarta, 1983

Abdy Yuhana, Sistem Ketatanegaraan Indonesia Pasca Perubahan UUD 1945: Sistem Perwakilan di Indonesia dan Masa Depan MPR RI, Focusmedia, Bandung, 2013.

Abdurrahman (ed). Beberapa Pemikiran Tentang Otonomi Daerah, PT. Media Sarana Gramedia Perss, Jakarta, 1987.

Adnan Buyung Nasution, Arus Pemikiran Konstitusionalisme: Tata Negara, Kata Hasta Pustaka, Jakarta, 2007. - dkk, Federalisme Untuk Indonesia, Penerbit Kompas, Jakarta, 1999.

Affan Gafar, Politik Indonesia; Transisi Menuju Demokrasi, Pustaka Pelajar, Yogyakarta, 2004.

Ahmad Sukardja, Hukum Tata Negara dan Hukum Administrasi Negara Dalam Perspektif Fikih Siyasah, Sinar Grafika, Jakarta, 2012.

Agus Djojosoekarto, dan Rudi Hauter, (Ed)., Pemilihan Langsung Kepala Daerah: Transformasi Menuju DemokrasiLokal, Kerjasama ADEKSI dan Konrad-Adenauer-Stiftung, Jakarta, 2006.

Agus Riwanto, Hukum Partai Politik dan Hukum Pemilu Di Indonesia: Pengaruhnya Terhadap Penyelenggaraan Pemilu Berkualitas dan Sistem Pemerintahan Presiden Presidensial Efektif, Thafa Media, Yogyakarta, 2016.

Ahmad Syafii Maarif, Islam dan Masalah Kenegaraan, LP3ES, Jakarta, 1985.

Aidul Fitriciada Azhari, Menemukan Demokrasi, Muhammadiyah University Press, Surakarta, 2005.

Alwi Dahlan, Makna Informasi Bagi Surat Kabar, Sinar Harapan, Jakarta, 1986.

Amrah Muslimin, Aspek-Aspek hukum Otonomi Daerah, Alumni, Bandung, 1978.

Anwar C., Teori dan Hukum Konstitusi, Setara Press, Malang, 2015.

Arbi Sanit, Perwakilan Politik di Indonesia, Rajawali Pres, Jakarta, 1985

Azhary, Ilmu Negara Pembahasan Buku Kranenburg, Ghalia Indonesia, Jakarta, 1983.

Badan Penerangan Amerika Serikat (United Stątes Information Agency), Garis Besar Sejarah Amerika, Jakarta, 1949.

Baechler, Jean, Demokrasi Sebuah Tinjauan Aanalitis, Yogyakarta: Kanisius, 2001.

Bagir Manan, Hubungan Antara Pusat dan Daerah, Sinar Harapan, Jakarta, 1994

--------------, Menyongsong Fajar otonomi Daerah, FH.UII, Cet.III, Yogyakarta, 2004.

Bagir Manan dan Kuntana Magnar, "Mewujudkan Kedaulatan Rakyat Melalui Pemilihan Umum”, dalam Bagir Manan (Ed), Kedaulatan Rakyat, Hak A sasi Mrnusia dan Negara Hukum, Gaya Media Pratama, Jakarta, 1996. 321

Bertens, K. Sejarah Filsafat Yunani, Yayasan I arta, 1975

BP 7, Pedoman Penghayatan dan Pengamalan Pancasila, BP 7, Jakarta, 1984.

Budiman Tanurejo, Akal akal Akil, Penerbit Kompas, Jakarta, 2014

Burns, Danny Robin Hambleton and Paul Hoggel, The Politics of Decentralisation, Revitalising Local Democracy, The MacMillan LTD, London, 1994. 
Busyro Muqoddas, Hegemoni Rezim Intelijen (Sisi Gelap Peradilan Kasus Komando Jihad),PUSHAM UII, Yogyakarta, 2011.

CSIS, Pandangan Presiden Soeharto tentang Pancasila, Yayasan Proklamasi, Jakarta, 1976.

Dahlan Thaib, Ketatanegaraan Indonesia Perspektif Konstitusional, Total Media, Yagyakarta, 2009.

Dahlan Thaib dan Ni'matul Huda (ed.), Pemilu dan Lembaga Perwakilan Dalam Ketatanegaraan Indonesia, Jurusan HTN Fakultas Hukum UII, Yogyakarta, 1992.

Dardji Darmodihardjo, Santiaji Pancasila.: Laboratorium IKIP Malang, Malang 1978.

Dasril Radjab, Hukum Tata Negara Indonesia, Rineka Cipta, Jakarta, 1994.

Denden Deni Hendri, Argumentasi Kebijakan Uji Publik Calon Kepala daerah, Pustaka Kemang, Depok, 2016.

Deliar Noer,Asas Tunggal Pancasila. Bulan Bintang, Jakarta, 1980.

Didik Sukriono, Hukum Konstitusi dan Konsep Otonomi. Kajian Politik Hukum tentang Konsitusi, Otonomi Daerah dan Desa Pasca Perubahan Konstitusi, Setara Press, Malang, 2013.

Eduardus Marius Bo, Teori Negara Hukum \& Kedaulatan Rakyat, Setara Press, Malang, 2019

Erfandi, Parliementary Theshold dan Ham Dalam Hukum Tata Negara, SETARA Press, Malang, 2014.

Ellyadar Chaidir, Sistem Pemerintahan Negara Republik Indonesia Pasca Perubahan Undang-Undang Dasar 1945, Total Media, Yogyakarta, 2008

Firdaus, Constitutional Engineering: Desain Stabilitas Pemerintahan Demokrasi \& Sistem Kepartaian, Irama Widya, Bandung, 2015.

Frans Magnis Suseno, Mencari Sosok Demokrasi, Sebuah Telaah Filosofis, Gramedia, Jakarta, 1997.

Gie,The Liang,Pertumbuhan Pemerintahan Daerah di Negara Republik Indonesia, Jilid III, Gunung Jakarta, Agung, 1988.

Gould, Carol C., Demokrasi Ditinjau Kembali, PT. Tiara Wacana, Yogyakarta. 1993.

Gunawan Suswantoro, Pengawasan Pemilu Partisipatif, Penerbit Erlangga, Jakarta, 2015.

H.Saidus Syahar, Pancasila Sebagai Paham Kemasyarakatan dan Kenegaraan Indonesia, Alumni, Bandung, 1977.

H. Nurhamin Nahar Usman, Percepatan dan Perlambatan Demokrasi di tingkat Lokal, Kompas Gramedia, Jakarta, 2015.

Hardiman. Demokerasi Delibratif, Yayasan kanisius. Jakarta 2016.

Harmaily Ibrahim, Majelis Permusyawaratan Rakyat, Sinar Bakti, Jakarta. 1979.

HAW. Widjaya, Penyelenggaraan otonomi di Indonesia, Rajagrafindo Persada, Jakarta, 2013.

Herwanto Sosronegoro, PerkembanganIdeologi di Dunia, Bintang Media, Yogyakarta, 1980

Feith, Herbert \& Lance Castles (eds.), Pemikiran Politik Indonesia 1945-1965, LP3ES, Jakarta, 1988

Herwanto Sosronegoro, Perkembangan Ideologi di Dunia,, Bintang Media, Yogyakarta, 1980.

Hook, Sidney. Percakapan Tentang Empat Filsafat. Djambatan. Jakarta, 1980.

I Dewa Gede Palguna, Pengaduan Konstitusional (Constitutional Complaint) Upaya Hukum terhadap Hak-Hak Konstitusional Warga Negara. Sinar Grafika Jakarta, 2013.

Ismail Suni, Pergeseran Kekuasaan Eksekutif, Aksara Bam, Jakarta, 1983.

Iver, Mac., The Web of Government, The Mac Millan Company, New York. 1954.

Janedjri M. Gaffar, Politik Hukum Pemilu, Konstitusi Press, Jakarta, 2012, hlm.93

I. Kaloh, Kepemimpinan Kepala Daerah, Sinar Grafika, Jakarta, 2009

Jimly Asshiddiqie, Hukum Tata Negara \& Pilar-pilar Demokrasi, Sinar Grafika, Jakarta, 2012

----------------, Pokok-Pokok Hukum Tata Negara, Buana Ilmu Populer, Jakarta, 2009

Konsolidasi Naskah UUD 1945 Setelah Perubahan Keempat, Pusat Study Hukum Tata Negara FH UI, Depok 2002

-, Konstitusi dan Konstitusionalisme Indonesia, Sinar Grafika, Jakarta, 2010

Johnny Ibrahim, Teori dan Metodologi Penelitian Hukum Normatif, Bayumedia Publishing, Malang, 2008.

Joko J. Prihatmoko, Pemilihan Kepala Daerah Langsung; Filosofi, Sistem, dan Problema Penerapan di Indonesia, Pustaka Pelajar, Yogyakarta, 2005.

Juri Ardiantoro (et.al), Transisi Demokrasi, Evaluasi Kritis Penyelenggaraan Pemilu 1999, Jakarta: KIPP. 1999.

Kacung Marijan, Sistem Politik Indonesia: Konsolidasi Demokrasi pasca Orde Baru, Kencana, Jakarta, 2010.

Kaelan, Negara Kebangsaan Pancasila, Paradigma, Yogyakarta, 2018.

--------, Pancasila Yuridis Kenegaraan, Paradigma, Yogyakarta, 1991.

Kelsen, Hans. General Theory of Law and State, New York: Russel \& Russel, 1975.

------------- (eds), Teori Umum Tentang Hukum dan Negara, Terjemahan Raisul Muttaqien, Nusa Media, Bandung, Cet.IX, 2014

Koentjaraningrat. Antropologi Budaya. Universitas Indonesia, Jakarta, 1978.

Koentjoro Poerbopranoto, Sedikit Tentang Sistim Pemerintahan Demokrasi, PT. Eresco, Bandung, 1975. 
Kusuma, RM.A.B., Sistem Pemerintahan "Pendiri Negara” Versus Sistem Presidensiel "Orde Reformasi”, Badan Penerbit fakultas Hukum Universitas, Jakarta, 2011.

Kusnadi dan Bintan Saragih, Ilmu Negara, Gaya Media Pratama, Jakarta, 1988

Laboratorium Pancasila IKIP Malang, Pancasila, Lab Pancasila. Malang, 1986.

Lemhannas. Pancasila Sebagai Ideologi Terbuka. Lembaga Ketahanan Nasional. Jakarta, 1992.

Maria farida Indrati S., Ilmu Perundang-Undangan: Jenis, Fungsi, dan Materi Muatan, Penerbit Kanisius, Yogyakarta, 2007.

M. Dawam Rahardjo (Ed.), Sistem Pemilu : Demokratisasi dan Pembangunan, PT. Pustaka Cidesindo, Jakarta, 1996.

M. Noor Azis, Pengkajian Hukum tentang Pemilihan Kepala Daerah, Badan Hukum Pembinaan HukumNasional, Jakarta, 2011.

M. Rusli Karim, Pemilu Demokratis Kompetitif, Tiara Wacana Yogya, Yogyakarta.

Mahsun, Akuntansi Sektor Publik. BPFE, Univesitas Gajahmada Yogyakarta. 2005.

Mahmuzar, Sistem Pemerintahan Negara Menurut UUD 1945 Sebelum dan Sesudah Amandemen, Nusa MediaUIN Suska, Bandung, 2010.

Majelis Permusyawaratan Rakyat Republik Indonesia, Panduan Dalam Memasyarakatkan Undang-Undang Dasar Negara Republik Indonesia Tahun 1945, Latar Belakang, Proses dan Hasil Perubahan UndangUndang Dasar Negara Republik Indonesia Tahun 1945, Sekretariat Jenderal MPR RI, Jakarta, 2003.

Maman Sulaiman, Agama Negara dan Hak Asasi Manusia. Perisai, Bandung, 2002.

Marc F., Plattner, Joao Carlos Espada, The Democratic Invention, Baltimore, The John Hopkins University Press. 2008.

Margarito Kamis, Jalan panjang Konstitusionalisme Indonesia, Setara Press, Malang, 2014.

------------, Kekuasaan Presiden Indonesia: Sejarah kekuasaan Presiden Sejak Merdeka Hingga Reformasi Politik, Setara Press, Malang, 2014.

Masrukin Hadi, Pola Otonomi Darah dan Pemberdayaan Masyarakat Menuju Civil Society. Lentera, Surabaya, 2004.

Miriam Budiardjo, Dasar-Dasar Ilmu Politik, PT. Gramedia, Jakarta, 1983.

, Dasar-Dasar Ilmu Politik, PT. Gramedia, Jakarta, 2001

Mochamad Isnaeni Ramdhan, Perubahan UUD 1945 Dengan Teknik Amandemen, Sinar Grafika, Jakarta, 2015.

Mochtar Kusumaatmadja, Pembinaan Hukum Dalam Rangka Pembangunan Nasional, Bina Citra, Bandung, 1972.

Moeljarto Tjokrowinoto, Beberapa Pokok Pikiran Tentang Sistem Kepartaian di Indonesia, Seksi Penerbitan Fakultas Sospol UGM, Jogyakarta, 1968.

Mohammad Hatta, Kumpulan Pidato II, Penyusun: I Wangsa Widjaya \& Meutia F.Swasono, Terbitan Khusus Satu Abad Bung Hatta Bekerjasama dengan PT. Toko Gunung Agung Tbk.,Jakarta, 2002.

Moh. Kusnadi \& Bintan R.Saragih, Ilmu Negara, Gaya Media Pratama, Jakarta, 1988 , Ilmu Negara, Edisi Revisi. Gaya Media Pratama, Jakarta, 2009.

Moh. Kusnadi dan Harmaily Ibrahim, Pengantar Hukum Tata Negara Indonesia, Pusat Studi HTN UI \& Sinar Bakti, Jakarta, 1983

Moh. Kusnardi dkk., Ilmu Negara, Gaya Media Pratama, Jakarta, 2000

Moh. Mahfud MD., Hukum dan Pilar-Pilar Demokrasi, Gama Media, Yogyakarta, 1999.

, Politik Hukum di Indonesia, PT. RajaGrafindo Persada, Jakarta, 2014

Muhadam Labolo, Dinamika Politik dan Pemerintahan Lokal, Ghalia Indonesia, Bogor, 2015.

Muhammad Yamin, Naskah Persiapan Undang-Undang Dasar 1945, yayasan Prapantja, Jilid I, Jakarta, 1976.

Munir Fuady, Teori Negara Hukum Modern (Rechtstaat), PT. Refika Aditama, Bandung, 2011. , Konsep Negara Demokrasi, PT. Rafika Aditama, Bandung, 2010.

Ni’matul Huda,Hukum Tata Negara Indonesia, PT.RajaGrafindo Persada, Jakarta, 2012.

Notonagoro. Pancasila Dasar Negara.. Universitas Gajahmada, Yogyakarta 1968.

-----------, Pancasila Dasar Negara, Pantjuran Tujuh, Jakarta, 1974.

, Tercapainya Konsensus Nasional 1966-1969, PN. Balai Pustaka, Jakarta, 1985

Nugroho Notosusanto. Tercapainya Konsensus Nasional 1966-1969. PN. Balai Pustaka, Jakarta. 1985. -, Proses Perumusan Pancasila Dasar Negara, PN Balai Pustaka, Jakarta, 1979.

Nurul Qamar, Hak Asasi Manusia dalam Negara Hukum Demokrasi ( Human Rights In Democratiche Rechtsstaat), Sinar Grafika, Jakarta, 2018.

Padmo Wahyono, Membudayakan UUD 1945, Ind. Hill, Jakarta, 1991.

Pambudi, Priofil Manusia Indonesia.Panepen Mukti, Solo, 2001.

Panitia Lima, Uraian Pancasila, Mutiara, Jakarta, 1980.

Peter Mahmud Marzuki, Penelitian Hukum. Jakarta : Prenada Media Group, 2007.

Philipus M.Hadjon, Lembaga Tertinggi dan Lembaga Tinggi Negara, Bina Ilmu, Surabaya, 1987 
----------------, Perlindungan Hukum Bagi Rakyat di Indonesia, Bina Ilmu, Surabaya, 1987.

Pilliang, Indra J. \& T.A. Legowo (Ed), Disain Baru Sistem Politik Indonesia, Centre for Strategic and International Studies, Jakarta, 2006.

Rachmat Hollyzon Mz, Sri Sundari, Pilkada Penuh Euforia, Miskin Makna, Bestari, Jakarta, 2014.

Rambe Kamarul Zaman, Perjalananan Panjang Pilkada Serentak, Penerbit Expose, Jakarta, 2016.

Ramdlon Naning, Cita dan Citra Hak Asasi Manusia di Indonesia. Lembaga Kriminologi UI., Jakarta, 1983.

Ranney, Austin The Governing of Men,: Holt Rinehart and Winston, New York, 1962.

Refly Harun, Hukum Sengketa Pemilu, Mekanisme Penyelesaian Perselisihan Hasil Pemilu di Mahkamah Konstitusi, Konstitusi Press, Jakarta, 2019.

Reves, Emery, A Democratic Manifesto, (diterjemahkan oleh A.Z.Abidin)' Sekolah Maklumat Demokrasi, Yayasan Pembangunan Jakarta, 1951.

Ricklef, M.C., Sejarah Indonesia Modern 1200-2004, PT. Serambi Ilmu, Jakarta, 2007.

Rifqinizamy Karsayuda, Partai Politik Lokal Untuk Indonesia - Kajian Yuridis Ketatanegaraan Pembentukan Partai Politik Lokal di Indonesia Sebagai Negara Kesatuan, PT. RajaGrafindo, Jakarta, 2015.

Rondinelli and Cheema,.Decentralization and Development: Policy Implementation in Developing Countries, Beverly Hills: Sage Publication, 1988

Rusadi Kartaprawira, Sistem Politik Indonesis, PT. Tribisana, Bandung, 1977.

Sado Wasistono, Kapita Selekta Manajemen Pemerintahan Daerah, Edisi Revisi, Fokusmedia, Bandung, 2003.

Saidus Syahar, Pancasila Sebagai Paham Kemasyarakatan dan Kenegaraan Indonesia, Alumni, Bandung, 1977. Syamsuddin Haris, Menggugat Politik Orde Baru, Grafiti, Jakarta, 1998.

Saldi Isra, Pergeseran Fungsi Legislasi: Menguatnya Model Legislasi Parlementer dalam Sistem zpresidensial Indonesia, PT RajaGrafindo Persada, Jakaarta, 2013.

Samsul Wahidin, Hukum Pemerintahan Daerah, Mengawasi Pemilihan Umum Kepala Daerah, Pustaka Pelajar, Yogyakarta, 2008

------------------, Hukum Pemerintahan Daerah: Pendulum Otonomi Daerah dari Masa Ke Masa, Pustaka Pelajar, Yogyakarta, 2013.

----------------, Pendidikan Kewarganegaraan, Pustaka Pelajar, Yogyakarta, 2014.

, Konseptualisasi dan Perkembangan Dewan Perwakilan Rakyat Republik Indonesia, Pustaka Pelajar, Yogyakarta, 2014

Samuel Huntington, P., "The Future of the Third Wave," dalam Plattner, Marc F., Espada, Joao Carlos,The Democratic Invention, Baltimore, The John Hopkins University Press. 2000.

Sarifuddin Sudding, Perselingkuhan Hukum dan Politik Dalam Negara Demokrasi, Rangkang Education, Yogyakarta, 2014.

Satya Arinanto, Hak Asasi Manusia dalam Transisi Politik di Indonesia, Pusat Studi Hukum Tata Negara Fakultas Hukum Universitas Indonesia,Jakarta, 2015.

Sekretariat Negara RI., Himpunan Risalah Sidang Sidang dari BPUPKI, Sekretariat Negara RI, Jakarta 1983. Diambil dari Muhammad Yamin. Naskah Persiapan Undang Undang Dasar 1945. Jilid Pertama. Jajasan Prapantja Jakarta, 1959.

Simorangkir, J.C.T., Penetapan Undang-Undang Dasar Dilihat dari Segi Ilmu Hukum Tata Negara, Gunung Agung, Jakarta, 1984.

Sodikin, Hukum Pemilu: Pemilu Sebagai Praktek Ketatanegaraan, Gramata Publishing, Bekasi, 2014.

Soehino, Ilmu Negara. Liberty, Yogyakarta, 1998.

---------, Perkembangan Pemerintahan di Daerah, Liberty, Yogyakarta, 1980.

, Selayang Pandang Tentang Sumber-Sumber Hukum Tata Negara Indonesia, Liberty, Yogyakarta, 1981.

Soerjono Soekanto dan Sri Mamudji, Penelitian Hukum Normatif Suatu Tinjauan Singkat, CV.Rajawali, Jakarta, 1985.

Soetandyo Wignjosoebroto, Hukum, Paradigma, Metode dan Dinamika Masalahnya, Huma, Jakarta, 2003.

Solichin Abdul Wahab, Masa Depan Otonomi Daerah, Penerbit SIC, Jakarta, 2002.

Sri Edi Swasono dan Fauzi Ridjal (Ed.), Mohammad Hatta: Beberapa Pokok Pikiran, Penerbit Universitas Indonesia, Jakarta, 1992.

Sri Soemantri Martosoewignjo, Bunga Rampai Hukum Tata Negara Indonesia, Alumni, Bandung, 1992.

Bandung, 1989

-, Tentang Lembaga-lembaga Negara Menurut UUD 1945, Citra Aditya Bakti,

, Tentang Lembaga-lembaga Negara Menurut UUD 1945, Alumni, Bandung, 1983. Rosdakarya, Jakarta, 2014

-, Bunga Rampai Hukum Tata Negara Indonesia, Alumni, Bandung.1992.

Sri Sumantri Martosoewignjo dan Bintan R Saragih, Ketatanegaraan Indonesia dalam Kehidupan Politik Indonesia (30 Tahun Kembali Ke Undang Undang Dasar 1945), Pustaka Sinar Harapan. Jakarta, 1993. 
Strong, C.F Modern Political Constitutions, Sidswick \& Jackson Limited, London, 1963.

Sudikno Martokusumo, Penemuan Hukum, Libery, Yogyakarta, 1998.

Sufrin Na,a , Dinamika Hukum dan Ilmu Perundang-undangan di Indonesia, Alumni, Bandung, 2008.

Suryo Sakti Hadiwijoyo, Negara, Demokrasi dan Civil Society, Graha Ilmu, Yogyakarta, 2012.

Syafi'i Inu Kencana Syafi' I, Sistem pemeringtahan Indonesia. Rineka Cipta, Jakarta, 2011.

Syahda Guruh Langkah Samudra, Menimbang Otonomi vs Federal: Mengembangkan wacana Federalisme dan otonomi Luas Menuju Masyarakat Madani Indonesia, PT. Remaja Rosdakarya, Bandung, 2000.

Taliziduhu Ndraha, Kybernologi: Sebuah Rekonstruksi Ilmu Pemerintahan. Rineka Cipta. Jakarta. 1995.

Taufiqurrohman Syahuri, Hukum Konstitusi, Proses dan Prosedur Perubahan UUD di Indonesia 1945-2002, Ghalia Indonesia, Bogor, 2004

Teguh Prasetyo dan Arie Purnomosidi, membangun Hukum Berdasarkan Pancasila, Nusa Media, Bandung, 2014.

Titik Triwulan Tutik, Konstruksi Hukum Tata Negara Indonesia Pasca Amandemen UUD 1945, Kencana Prenada Media Group, Jakarta, Cet.ke-2, 2011. -, Pokok-Pokok Hukum Tata Negara Indonesia, Prestasi Pustaka, Jakarta, 2006

Tim Penyusun. Ensiklopedi Politik Pembangunan Pancasila jilid 3. Jakarta: Yayasan Tjiptaloka Caraka. 1983.

Tocqueville, Alexis de, Democracy in America, American. New York: Libraru, (terjemahan dalam Bahasa Indonesia) diterbitkan oleh Bhratara, Jakarta, 1960.

Tjahyo Kumolo, Politik Hukum Pilkada Serentak, Penerbit Expose, Jakarta, 2015.

Valina Singka Subekti, Menyusun Konstitusi Transisi: Pergulatan Kepentingan dan Pemikiran dalam Proses Perubahan UUD 1945, Rajawali Pers, Jakarta, 2008.

Von Schmid, J.J. Ahli-ahli Pikir Besar Tentang Negara dan Hukum (Dari Plato sampai Kant), PT. Pembangunan, Jakarta, 1965.

Wahyu Iryana, Historiografi Barat, Humaniora, Bandung, 2014

Ward, Ian (eds), Pengantar Teori Hukum Kritis, Narulita dan M. Khozim, Nusa Media, Bandung, Cet.I, 2014

Wilopo, Zaman Pemerintahan Partai-partai dan Kelemahan-kelemahannya, Yayasan Idayu, Jakarta, 1976

William, Liddle, R., Crafting Indonesian Democracy, Mizan, Bandung 2001.

Wiryono Prodjodikoro, Asas-asas Hukum Tata Negara di Indonesia, Dian Rakyat, Jakarta, 1989.

Yahya Muhaimin, Bisni dan Politik, Kebijaksanaan Ekonomi Indonesia 1950-1980, LP3ES, Jakarta, 1991.

Yosep Riwu Kaho, Otonomi yang Titik Beratnya Diletakkan Pada Daerah TK II, FISIPOL Universitas Gajah Mada, Yogjakarta, 1980.

Yudha Pandu (Ed.), UUD 1945 \& Konstitusi Indonesia, Indonesia Legal Center Publishing, Jakarta, 2008.

Yudi Latif, Negara Paripurna: Historisitas, Rasionalitas, dan Aktualitas Pancasila, PT. Gramedia Pustaka Utama, Jakarta, 2015.

Yusril Ihza Mahendra, Dinamika tata Negara Indonesia, Gema Insani Press, Jakarta, 1996.

Zainal Arifin Hoesein dan Rahman Yasin, Pemilihan Kepala Daerah Langsung Penguatan Konsep dan Penerapannya, Lembaga Pengembangan Pendidikan anak Bangsa (LP2AB), Jakarta, 2015.

\section{B. DISERTATION}

Azis Setyagama, Politik Hukum Pengaturan Pemilihan Kepala Daerah Berbasis pada Konstitusi, Disertasi pada Universitas Brawijaya, Malang, 2013

Aulia A. Rachman, Sistem Pemerintahan Presidentil Sebelum dan Sesudah Perubahan UUD 1945: Studi Ilmiah tentang Tipe Rezim, Tipe Institusi, dan Tipe Konstitusi, Program Doktor Pascasarjana Fakultas Hukum Universitas Indonesia, Jakarta, 2007

Gamawan Fauzi, Pengaruh Pemilihan Kepala Daerah Langsung Terhadap Korupsi Kepala Daerah di Indonesia, Disertasi, IPDN, Jakarta, 2014

Hamid S. Attamimi, A., Peranan Keputusan Presiden Republik Indonesia Dalam Penyelenggaraan Pemerintahan Negara, Fakultas Pascasarjana UI., Jakarta, 1990

Suharizal, Implikasi Pemilihan Kepala Daerah Langsung Terhadap Pertumbuhan Demokrasi dan Jalannya pemerintahan di Daerah, Disertasi pada Universitas Pedjadjaran, Bandung, 2015.

I Gde Pantja Astawa, Ruang Lingkup dan Pelaksanaan Wewenang Presiden Berdasarkan Ketentuan UndangUndang Dasar 1945, Thesis pada Universitas Pedjadjaran, Bandung, 1992.

\section{JOURNAL}

Ananda B. Kusuma, R.M., "Sistem Pemerintahan Indonesia", Jurnal Konstitusi, Vol.I No.1., Mahkamah Konstitusi Republik Indonesia, Jakarta, 2004.

Anton Djawamaku dan M. Sudibjo, “Perubahan UUD 1945: Solusi atau Problem Konstitusi ?", Jurnal Analisis 
CSIS, Tahun XXXI No.3., Centre for Strategic and International Studies, Jakarta, 2002.

Andy Ramses, "Pemilihan Kepala Daerah Secara Langsung dan Perlunya Revisi Terbatas Undang-Undang Nomor 22 Tahun 1999, Jurnal Ilmu Pemerintatahan, Edisi 19 Tahun 2003.

Muhsan, "Undang-undang Nomor 22 Tahun 1999 dalam Perspektif Yuridis dalam Wacana, Jurnal Ilmu Sosial Transformatif, Edisi 5 Tahun II, 2000.

Wicipto Setiadi, "Makna Persetujuan Bersama atas rancangan Undang-undang yang telah Mendapat Persetujuan Bersama", Jurnal Legislasi Indonesia, Vol.1, No.2., September, Direktorat Jenderal Perundangundangan Departemen Hukum dan HAM, Jakarta, 2004.

Departemen Pendidikan dan Kebudayaan, Kamus Besar Bahasa Indonesia, Balai Pustaka, Jakarta, 1990. Poerwadarminta, WJS., kamus Umum Bahasa Indonesia, PN.Balai Pustaka, Jakarta, 1976

\section{PAPER}

Soetandyo Wignyosoebroto, Negara dan Masyarakat. Makalah pada diskusi Civil Society pada Fakultas Ilmu sosial dan Ilmu Politik Universitas Airlangga Surabaya. 1978.

Mohammad Hatta, “Demokrasi Kita”, Majalah Panji Masyarakat, Jakarta, 1960

Prawoto Mangkusasmito, "Sekali Lagi Tempat Hukum dalam Alam Revolusi”, Majalah Hikmah, No.17 September 1960

A.Syafii Maarif, “Islam di Masa Demokrasi Liberal dan Demokrasi Terpimpin”, Majalah Prisma, No.5 Tahun 1988

\section{F. NEWSPAPER}

Ali Masykur Musa,’Pilpres Langsung”, Sinar Harapan, 30 Januari 2003

Darmaputera E., Pemimpin Formal, Pemimpin Informal, Harian Umum Sore Sinar Harapan, Sabtu, 03 Juli 2004. Moh. Mahfud MD., "Demokrasi, Integrasi, Makar”, Koran Sindo, Sabtu, 14 Januari 2017, hlm.15

Ramlan Surbakti "Parpol dan Masyarakat Warga”, Kompas, Jumat, 26 September 2014.

Yudi Latif, "Demokrasi tanpa Hikmat-Kebijaksanaan", Kompas, Selasa, 30 September 2014.

Rafly Harun, "Pilkada dan Lorong Ideologi Alternatif ", Kompas, rabu, 24 September 2014.

\section{G. INTERNET}

http://alpari-forex.com/id/beginner/glossary/wto/, http://law.ub.ac.id/disertasi-azis-politik-hukum-Pilkada-berbasis-konstitusi/ http://totabuan.co/2014/09/mendagri-319-kepala-daerah-dan-wakil-kepala-daerah-tersangkut-kasus-korupsi/ http://www.cnnindonesia.com/politik/20140919170605-32-://news.unpad.ac.id/?p=366523808/mendagri-rawankorupsi-bukan-alasan-Pilkada-kembali-ke-dprd/ 